\title{
SOME REMARKS ON GRAMMATICAL ASPECT IN LATIN
}

\section{Olga Spevak}

Université de Toulouse 2 JJ. Département de lettres et de langues anciennes

Bâtiment Gai savoir 5, allées Antonio Machado 310 58, Toulouse, cedex 9, France; spevak@univ-tlse2.fr

The existence of grammatical aspect in Latin is a much discussed issue. The main aim of this article is to review different approaches to this question and to discuss important arguments that have to be taken into consideration. Besides the traditional view according to which there is an aspectual difference between the infectum and perfectum stems, two other arguments claiming the existence of aspect in Latin have been proposed: aspect as a category inherited from Indo-European and aspectual difference between the Latin perfect and imperfect tense. On the one hand, I will argue that the difference between the perfect and the imperfect is of a temporal nature and that the Latin perfect is used both for telic (terminative) states of affairs and atelic (non-terminative) ones. Furthermore, the Latin perfect combines with expressions of duration which, except for special cases, are excluded with Russian perfective verbs.

Keywords: Grammatical (verbal) aspect, perfect tense, imperfect tense, perfective, imperfective, duration, narrative, foreground, background.

\section{Introduction*}

This article deals with grammatical (verbal) aspect. As a grammatical category, aspect is defined as "different ways of viewing the internal temporal constituency of a situation" (Comrie 1976, 3). When talking about grammatical aspect (i. e. expressed by morphological means), "perfectivity indicates the view of the situation as a single whole, without distinction of the various separate phases that make up that situation, while the imperfective pays essential attention to the internal structure of the situation" (ibid., p. 16). Lexical aspect (Germ. Aktionsart) is a term for expressing aspect by lexical means (iterativity, inchoativity, distributivity, etc.).

According to Szemerényi $(1987,7)$, there are two almost generally accepted systems of grammatical aspect:

- in Ancient Greek, where aspect does not form a separate category but is linked with tense (the so-called aspecto-temporal system). Especially three aspectual values are

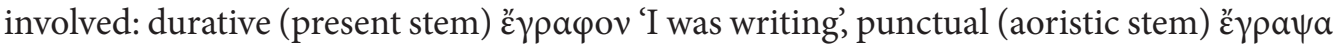
'I wrote', and resultative (perfect stem) $\gamma \varepsilon \dot{\varepsilon} \gamma \rho \propto \varphi \alpha$ 'I have written';

- in Slavic languages, where grammatical aspect is developed from verbal prefixes or preverbs: pisat' (imperfective verb) - napisat' (perfective verb), and suffixes: perepisat' (perfective verb) - perepisyvat' (imperfective verb). Suffixes are mainly found with the so-called secondary imperfectives, $i$. e. imperfective verbs derived from perfective ones.

* I would like to express my gratitude to Elena Zheltova for offering me the possibility to participate in the The Joseph M. Tronsky XX Memorial Annual International Conference Indo-European Comparative Linguistics and Classical Philology in June 2016, where I presented a shorter version of this text. I would also like to thank Prof. N. Kazansky for his warm welcome. My special thanks go to the anonymous reviewer for his/her suggestions; I am aware of the fact that lot of has been written on aspect and that my references are too selective.

(C) St. Petersburg State University, 2016 
From a morphological point of view, Latin has both several verbal stems as Ancient Greek, and verbal prefixes as Slavic languages. The question is whether these means fulfil the same function as in Ancient Greek and in Slavic languages.

Latin has two verbal stems, called "infectum" and "perfectum" (see Table 1). These appellations, which evoke the aspectual distinction in Slavic languages, are conventional and go back to the Roman grammarian Varro $\left(1^{\text {st }}\right.$ century $\left.\mathrm{BC}\right)$. From a traditional point of view (Szantyr 1972, 300), these two stems are supposed to reflect an inherited aspectual imperfective - perfective distinction:

laudo 'I praise' (infectum stem) - laudavi 'I have praised' (perfectum stem).

In other words, the tenses formed from the infectum tense are supposed to have an imperfective value and the tenses from the perfectum stem, a perfective value.

Table 1: Survey of Latin tenses (active voice) - Pinkster $(2015, \S 3.12,56)$

\begin{tabular}{|c|c|c|c|c|c|}
\hline \multicolumn{3}{|c|}{ The infectum stem } & \multicolumn{3}{|c|}{ The perfectum stem } \\
\hline tense & indicative & subjunctive & tense & indicative & subjunctive \\
\hline present & $\begin{array}{l}\text { dele-o } \\
\text { 'I am destroing' }\end{array}$ & dele-am & perfect & $\begin{array}{l}\text { delev-i } \\
\text { 'I have destroyed' }\end{array}$ & delev-erim \\
\hline imperfect & $\begin{array}{l}\text { dele-bam } \\
\text { 'I was destroying' }\end{array}$ & dele-rem & pluperfect & $\begin{array}{l}\text { delev-eram } \\
\text { 'I had destroyed' }\end{array}$ & delev-issem \\
\hline future & $\begin{array}{l}\text { dele-bo } \\
\text { 'I will destroy' }\end{array}$ & & future perfect & $\begin{array}{l}\text { delev-ero } \\
\text { 'I will have } \\
\text { destroyed' }\end{array}$ & \\
\hline
\end{tabular}

However, Latin does not exactly continue the threefold Indo-European distinction between the present, aoristic, and perfect stem. The Latin perfect, often viewed as a merger of the Indo-European aoristic and perfective stems, is in fact new creation, although the morphemes used in the most regular verbs, $-a v$ - and $-e v$-, are of unclear origin; only some aoristic (scripsi 'I have written') and perfective (with reduplication, cucurri 'I have run') forms have survived as residual.

Apart from this traditional view, it has also been claimed that the aspectual opposition in Latin resides in pairs: simple verb vs compound verb as in Slavic languages; simple verbs are supposed to exhibit an imperfective value, compound verbs, a perfective value, for example, sequor 'to follow' vs adsequor 'to pursue' (Meillet 1897 and Meillet \& Vendryès 1948, 301-3). Van der Heyde (1926) has convincingly shown that this theory is untenable, since Latin verbal prefixes always have a lexical value. There is an additional argument against this view: both simple (miror 'to wonder') and compound verbs (inrideo 'to laugh at', exerto 'to stick out') can be combined with verbs expressing phases of an event, such as 'to begin', 'to stop', see examples below. For semantic reasons, these verbs cannot be used for an event which is already complete: one cannot start or stop something which is already accomplished. Therefore, the infinitives in (1) and (2) must have an imperfective value: mirari corresponds to udivliat'sia (1), inridere to smeiat'sia, and exertare to vysovyvat'. In Slavic languages, only imperfective verbs (primary or secondary) can be used with these verbs; combinations with perfective verbs would be ungrammatical ( ${ }^{*}$ nachat' posmeiat'sia).

(1) desinite mirari (Rhet. Her. 4, 36)

'cease to wonder' 
(2) Deinde Gallus inridere coepit atque linguam exertare. (Quadr. Ann. frg. 10b, ap. Gell. 9, $13,12)$

'Then the Gaul began to laugh at them and to stick out his tongue.'

The traditional approach following Szantyr $(1972,300)$ has been criticised, especially by Pinkster $(1983,296$, and $2015, \$ 7.3,380-1)$, who has objected that the imperfective perfective opposition does not affect the Latin tense system as a whole but is only partial. Instead of a mixed inherited aspecto-temporal category, for which there is little support in Latin, he envisages a purely temporal category for Latin tenses and describes them as a relative tense system where notions such as anterior, simultaneous, and posterior apply, with respect to the time of speaking: the past, the present, and the future (see Pinkster $2015, \S 7.4,384$ for more detail).

Despite of this convincing explanation, which is first of all systematic in that it encompasses not only the indicative but also the subjunctive and the imperative mood as well as verbo-nominal forms (infinitives and participles), the discussion about the existence of grammatical aspect has arisen once again and two other claims have been made. Firstly, from a point of view of Indo-European linguistics, Oldsjö (2001, 52-73) has suggested that since grammatical aspect is supposed to have existed in Indo-European, it must have been inherited by Latin as well. This assumption is wrong from a methodological point of view: Latin data cannot be interpreted on the basis of a putative grammatical category in Indo-European. Secondly, Haverling (2010, 437ff.) has argued that there is an inherited aspectual opposition in Latin, between the perfect and the imperfect tense, perceptible especially in narrative texts. In the following sections, I will discuss arguments against these claims in more detail.

\section{Latin perfect and imperfect - an aspectual opposition?}

The most important objections against the existence of grammatical aspect in Latin can be summarised in three points:

a) the opposition between the perfect tense and the imperfect tense is not a systematic opposition because it is restricted to the indicative mood only;

b) the putative aspectual opposition between the perfect tense and the imperfect tense is confused with functions of these Latin tenses in narrative texts;

c) combinability of the Latin perfect with expressions of duration is not taken into consideration in a sufficient way.

I will pay special attention to points b) and c) in sections 2.1 and 2.2 , respectively. ${ }^{1}$

\subsection{Narrative vs descriptive tense}

Unlike most of Slavic languages (except for Bulgarian), Latin has two tenses, the perfect and the imperfect, for referring to past events, and one pluperfect for the expression of anteriority in the past. Following Weinrich (1964), two levels of narrative are distinguished: the foreground level corresponding to the main narrative line and the back-

\footnotetext{
${ }^{1}$ For the point a), see Kravar $(1980,129)$ and Pinkster $(1983,296 ; 2015, \S 7.3,380-1)$. The Latin perfect does not only enter in opposition with the imperfect but also with the present and, as for subjunctives, there is no perfect vs imperfect opposition at all.
} 
ground level that serves for description of circumstances. In a narrative, the Latin perfect is used for narration of main events, and the imperfect for descriptions (3). ${ }^{2}$ The question is: what is the nature of this opposition?

(3) Cenabam apud Seium, cum utrique nostrum redditae sunt a te litterae. (Cic. Fam. 9, 7, 1) 'I was at dinner with Seius when a letter from you was delivered to each of us.'

Is the difference between the imperfect cenabam and the perfect redditae sunt a difference of aspect, since both the perfect and the imperfect are past tenses (Comrie 1976, $3)$ ? Haverling $(2010,438)$ actually claims that it is an aspectual difference. There are two problems.

The first one is that a "specialisation" of the use of tenses in a narrative (narrative tense, descriptive tense) is secondary. Whatever the difference between them is, a language will not develop such an opposition for narratives only. These tenses have their own semantic value: the perfect expresses an event which is finished in the moment of speaking, the imperfect expresses an ongoing event in the past. ${ }^{3}$ Sometimes a perfect tense can suggest a "perfective" interpretation and an imperfect tense, an "imperfective" interpretation, but this is only a side effect, as in (3) where cenabam actually has an imperfective value and is translated by uzhinal in Russian, and redditae sunt has a perfective value, Rus. byl peredan. However in (4), the imperfect peribat corresponds to the imperfective umiral but the perfect vidi is translated by the imperfective videl.

(4) Quin ego quom peribat vidi. (Plaut. Bacch. 469)

'I even saw him when he was dying.'

The second problem is that regarding the difference between a narrative tense (Latin perfect) and a descriptive tense (Latin imperfect) as an aspectual opposition is forgetting the discussion of Slavic linguists about the situation in Old Church Slavonic where the aorist and the imperfect and the emerging aspectual - imperfective and perfective pairs of verbs coexist. Dostál $(1954,598-9)$ has convincingly shown that the aorist imperfect opposition in Old Church Slavonic is of a temporal nature: the aorist expresses "finished, accomplished" events, and therefore it is suitable for narration; the imperfect expresses "ongoing" events in the past - and is thus used for descriptions. ${ }^{4}$ As Dostál (ibid.) demonstrates, the fact that an event is finished - he himself terms it Cz. časová hotovost (vremennaia gotovost') - is not the same thing as perfectivity, and the fact that an event is ongoing is not the same thing as imperfectivity. In this context, it is also worth mentioning Havránek (1939) and Maslov $(1985,28)$ who also distinguish "temporality" from "aspectuality". By the way, some languages can exhibit a relatively rich system of past tenses (Černý 1970, 214) but such a subdivision is not necessarily an indicator of the existence of the grammatical aspect.

To sum up, the Latin tense system has two past tenses: the perfect expresses an event which is finished in the moment of speaking, the imperfect expresses an ongoing event in the past. These tenses are used for structuring a narrative: at the foreground level, the perfect, and at the background level, the imperfect. This opposition is linked with hierarchi-

2 This example is taken from Haverling $(2010,438)$.

3 See Pinkster $(2015, \S 7.18,410$ and $\$ 7.30,442)$.

4 Tenses in modern Bulgarian are a continuator (with some modification) of the Old Church Slavonic system. 
cal subdivision of events and circumstances, which has nothing to do with grammatical aspect. In Russian, there is no such a means for indicating what belongs to the narrative line and what are secondary circumstances.

\subsection{Expressions of duration}

There is another point that is not taken into consideration in a due way in the literature about aspect: combinability of verbs with expressions of duration.

Temporality and relationship with different time expressions are indeed crucial for any consideration of aspect. Vendler (1957/1967) elaborated four main categories of state of affairs, starting from a preliminary distinction of telic (terminative) states of affairs ( $T$ ), which are brought to an end, and atelic (non-terminative) states of affairs (A), which do not imply an end. They are summarised in Table 2 .

Table 2: Categories of state of affairs with English examples

(following Vendler 1957)

\begin{tabular}{|ll|}
\hline STATE (A) & to live for some time / since \\
ACTIVITy (A) & to write for some time / since \\
ACCOMPLishment (T) & to write in some time \\
ACHIEVEMENT (T) & to win at a moment \\
\hline
\end{tabular}

If the opposition between the Latin perfect and imperfect - or more generally, between the perfectum stem and the infectum stem - were an aspectual opposition, one would expect that atelic states and activities are expressed by the imperfect, and telic accomplishments and achievements by the perfect. However, Kravar (1980, 152; cf. Tronsky 1973) has shown that states and activities can be expressed in the perfect in Latin and can correspond to imperfective verbs in Croatian and in Russian, for example in (5). Furthermore, they can be combined with expressions of duration, such as noctem perpetem "the entire night" (accusative of duration).

(5) Ibi cenavi atque ibi quievi in navi noctem perpetem. (Plaut. Amph. 732-5)

'There I had dinner (uzhinal) and there I rested (spal) the entire night on the ship.'

The Latin perfect is normally used for states and activities which last some time; the Latin imperfect is by no means "specialised" in expressing durative events. According to Torrego $(1989,267)$, in Livy there are 47 perfects vs 16 imperfects with expressions of duration. Further examples are not difficult to find, of states (6), or activities (7)-(8).

(6) Adest, adest fax..., multos annos latuit (Enn. Trag. 63, ap. Cic. Div. 1, 67),

'It comes, it comes, that torch ... though hid from sight (byla skrytaia) for many years.'

(7) Itaque (pecunia) usus est menses XIIII. (Cic. Att. 7, 7, 2)

'Accordingly, he used (ispol'zoval) the money for fourteen months.'

(8) Biennium provinciam obtinuit. (Cic. Verr. 2, 3, 216)

'He governed (upravlial) the province for two years.'

Whereas the Latin perfect is combinable with expressions of duration, there are restrictions in Slavic languages (Table 3). 
Table 3: Categories of state of affairs with Russian examples.

\begin{tabular}{|ll|}
\hline STATE (A) & zhit' sorok let / dolgo / 'to live forty years / longtime' \\
aCtivity (A) & pisat' chas / dolgo 'to write for an hour' / longtime \\
ACCOMPlishment (T) & napisat'za chas 'to write in an hour' \\
ACHIEVEMENT (T) & pobedit' (kogda?) 'to win (at which moment?) \\
\hline
\end{tabular}

In particular, imperfective - perfective pairs seem to be in a complementary distribution in that for activities imperfective verbs are used (pisat'), whereas for accomplishments, their perfective counterparts (napisat'). Verbs expressing states usually do not form aspectual pairs. ${ }^{5}$ In Latin - as well as in English - the verb is formally the same (to write) for activities and for accomplishments but it can be combined with different temporal expressions and their aspectual interpretation depends on the context in which they are used.

From this it can be argued that the Latin perfect tense is aspectually neutral: it can be used in a "perfective" or an "imperfective" context. In the case of action verbs, Latin scripsi 'I wrote' can cover actions as well as accomplishments in Vendler's terminology, but in Russian, as we have seen, actions require an imperfective verb; and accomplishments, a perfective verb.

\section{Conclusions}

Claiming that Latin must have inherited grammatical aspect from its Indo-European ancestor is not a sufficient argument for proving the existence of this grammatical category. There are important factors that have to be taken into consideration when envisaging aspectual oppositions in Latin: (a) the functioning of aspect in the system of tenses (and moods), which is not the case when one restricts aspect to the Latin perfect and the imperfect; (b) the relationship between tenses and aspect, more specifically, between the function of tenses (narrative/descriptive) in narration and aspect, as it has been shown for Old Church Slavonic and Bulgarian; and (c) combinability with expressions of duration. Application of these criteria suggests that the Latin system of tenses does not show an aspectual opposition.

\section{References}

Comrie B.Aspect: An Introduction to the Study of Verbal Aspect and Related Problems. Cambridge, CUP, 1976.

Černý J. O vzniku a vývoji gramatických kategorií [On the origin and development of grammatical categories], Slovo a slovesnost 1970, 31, 207-222 (In Czech).

Dostál A. Studie o vidovém systému v staroslověnštině. Prague, SPN, 1954 [A study on the aspectual system in Old Church Slavonic] (in Czech).

Haverling G. Actionality, tense, and viewpoint, in: P. Cuzzolin and Ph. Baldi (eds.), New Perspectives on Historical Latin Syntax, 2, Constituent Syntax: Adverbial Phrases, Adverbs, Mood, Tense, Berlin, Mouton de Gruyter, 2010, 277-523.

Havránek B. Aspect et temps du verbe en vieux slave, in: Mélanges de linguistique offerts à Charles Bally, Genève, Georg 1939, 223-230.

Heyde van der, K. Composita en verbaal aspect bij Plautus, dissertation, Amsterdam, 1926.

\footnotetext{
${ }^{5}$ Aspectual pairs in Slavic languages typically concern "mutative verbs" that imply some change.
} 
Kravar M. Pitanja glogolskogo vida u latinskom jeziku. [Questions of verbal aspect in Latin language] Skopje, Živa antika, 1980 (In Chroatian).

Maslov Y. An outline of contrastive aspectology, in: Y. Maslov (ed.), Contrastive Studies in Verbal Aspect in Russian, French, and German, Heidelberg, Groos, 1985, 1-44.

Meillet A. and Vendryès, J. Traité de grammaire comparée des langues classiques. Paris, Champion, ${ }^{2} 1948$.

Meillet A. De l'expression de l'aoriste en latin. Revue de Philologie 1897, 21, 81-90.

Oldsjö F. Tense and Aspect in Caesar's Narrative. Uppsala, UP, 2001.

Pinkster H. Tempus, Aspect, and Aktionsart in Latin, in: W. Haase (ed.), Aufstieg und Niedergang der römischen Welt 2, 29, 1, Berlin, De Gruyter, 1983, 270-320.

Pinkster H. The Oxford Latin Syntax. Oxford, OUP, 2015.

Szantyr A. Lateinische Syntax und Stilistik. Munich, C. H. Beck, 1972.

Szemerényi O. The origin of aspect in the Indo-European languages. Glotta 1987, 65, 1-18.

Torrego E. Restricciones de la categoría verbal aspecto sobre los elementos de duración en latín. Minerva $1989,2,259-278$.

Tronsky I. M. Bemerkungen zum Aspekt- und Tempussystem des lateinischen Verbums, in: K. Strunk (ed.), Probleme der lateinischen Grammatik, Darmstadt, WB, 1973, 354-367.

Vendler Z., Verbs and times, in Z. Vendler, Linguistics in Philosophy, 1957/1967, 97-121.

Weinrich H. Tempus: Besprochene und erzählte Welt. Stuttgart, Kohlhammer, 1964.

For citation: Spevak O. Some Remarks on Grammatical Aspect in Latin. Philologia Classica 2016, 11(2), 282-288. DOI: $10.21638 / 11701 /$ spbu20.2016.207

\section{К ВОПРОСУ О КАТЕГОРИИ ВИДА В ЛАТИНСКОМ ЯЗЫКЕ}

\section{Ольга Спевак}

Наличие или отсутствие грамматической категории вида в латинском языке - это одна из дискуссионных проблем. Главной целью данной статьи является критический обзор существующих подходов к данной проблеме и анализ аргументов, существенных для ее решения. Помимо традиционной точки зрения, согласно которой существует видовое различие между основами инфекта и перфекта, в научной литературе выдвигается два других аргумента в пользу существования категории вида в латыни: вид как категория, унаследованная из праиндоевропейского языка, и видовое различие между латинским перфектом и имперфектом. Задача настоящей статьи - показать, что разница между перфектом и имперфектом в латыни имеет временную, а не видовую природу и что перфект используется для передачи как терминативных, так и нетерминативных значений. Кроме того, он может сочетаться с выражениями длительного действия, что, за исключением некоторых случаев, невозможно с глаголами совершенного вида в русском языке.

Ключевые слова: категория вида, перфект, имперфект, перфектив, имперфектив, выражение длительности, нарратив, нарративное время, дескриптивное время. 